\title{
Detrital zircon ages of Neoproterozoic sequences of the Moroccan Anti-Atlas belt
}

\author{
Jacobo Abati ${ }^{a, *}$, Abdel Mohsine Aghzer ${ }^{b, 1}$, Axel Gerdes ${ }^{c, 2}$, Nasser Ennih ${ }^{b}$

 \\ b Departament Géologie, Faculte des Sciences, Université Chouaib Doukkali, El Jadida, Morocco \\ ' Institut für Geowissenschaften, Mineralogie, Goethe-University Frankfurt (GUF), Aitenhöferallee 1, D-60438 Frankfurt am Main, Germany
}

Keywords:

Anti-Atlas belt

Morocco

Detrital zircon

$\mathrm{U}-\mathrm{Pb}$

\begin{abstract}
A B S T R A C T
Detrital zircon dating from Neoproterozoic successions in the Sirwa inlier of the Anti-Atlas belt in Morocco confirms that the maximum depositional age of the main stratigraphic groups is significantly younger than has been previously proposed in lithostratigraphic correlations. This can probably be extended to the whole Anti-Atlas according to other recent data from the Saghro inlier. Although the relative stratigraphic position of the different units remains valid as published previously, a crucial implication of the new ages is that the sequences believed to be contemporaneous with oceanic crust and island arc formation during the rifting and break-up of the northern margin of the West African Craton(WAC), and believed to be involved in the first phases of the Pan-African orogeny, are actually late to postorogenic. The age of the main deformation associated with the collision of the oceanic-and arc-derived terranes to the WAC, allegedly affecting the sediments of the Saghro Group, has been estimated at around 663-640 Ma. However, the youngest zircon populations of sediments of the Saghro and Bou Salda Groups, obtained in this study, cluster around 620-610 Ma, constraining the maximum age of deposition. This age of sedimentation is ind istinguishable from the age of intrusive high-K calc-alkaline plutons of the Assarag Suite, sugges ting a very rapid cycle of magmatism, relief formation, erosion and sedimentation in an active geodynamic scenario. Moreover, the proportion of the $610 \mathrm{Ma}$ detrital zircons becomes less with respect to the Paleoproterozoic zircons at higher stratigraphic levels, suggesting that the source of young zircons was progressively eroded and more extensive cratonic areas, that probably underlie the Neoproterozoic rocks, were exposed. We interpret these data in terms of the development of a ca. 610 Ma magmatic arc, built upon WAC basement, and its progressive dismantling. This arc can be correlated with the voluminous late Neoproterozoic (ca. 640-570 Ma) arc magmatism characteristic of the north Gondwana margin and the peri-Gondwanan terranes. The diamictite beds that appear in the Imghi Formation of the Saghro Group have been correlated with the Sturtian glacial period ca. $700 \mathrm{Ma}$. However, zircons from one sample of these diamictites indicate that this correlation cannot be longer maintained, and instead they should be correlated with the Marinoan glacial period ca. 630-610 Ma, with a widespread distribution of glaciogenic deposits in West Africa. In addition, around $375 \mathrm{U}-\mathrm{Pb}$ concordant analyses obtained from Paleoproterozoic zircons from six samples represent a statistically significant population of this area of the WAC basement, which can be a useful database for comparison with the detrital zircon populations of the peri-Gondwanan terranes of Europe and North America, as the WAC margins were one of the major sediment suppliers for these terranes.
\end{abstract}

\section{Introduction}

Determining the age of statistically meaningful populations of detrital zircons within clastic sedimentary rocks has proven to be a powerful method to obtain relevant information on the nature of the crustal elements in the source region. This information has helped to resolve paleogeographic positions and geodynamic realms of terranes and paleocontinents by comparing the ages of the sediment provenance areas with the zircon signature of the stable cratonic areas of old continents or with the age of characteristic tectono-metamorphic events. Recently, detrital zircon spectra have been widely used in the paleogeographic reconstruction of the Neoproterozoic margin of north Gondwana and the complex ensemble of terranes which originated around this margin (Fig. 1); the peri-Gondwanan terranes (e.g. Fernández-Suárez et al., 2002, 2003; Avigad et al., 2003; Murphy et al.., 2004; Linnemann et al., 


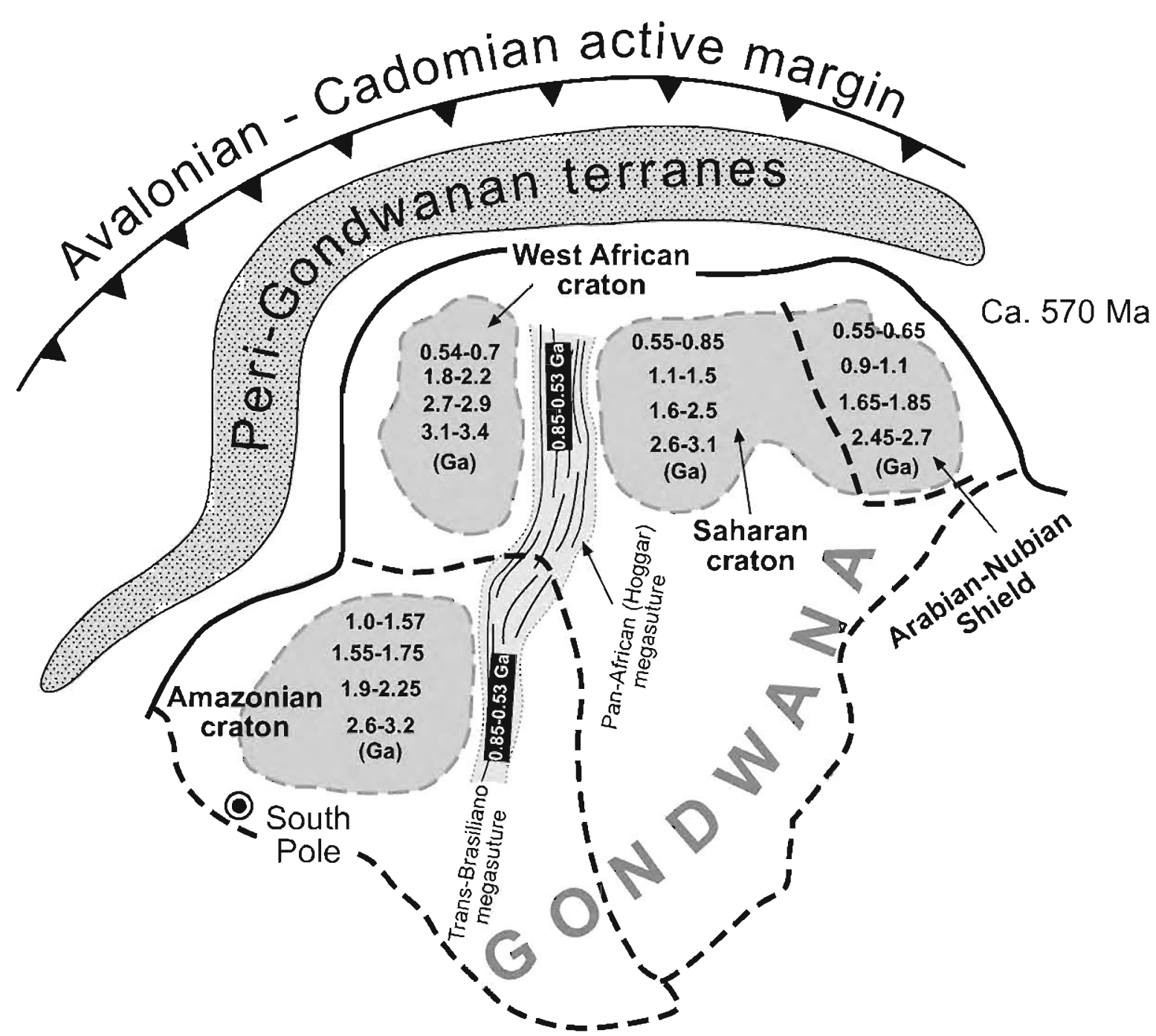

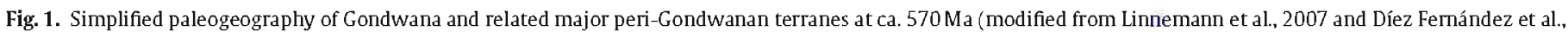
in press). Numbers in the cratonic areas summarize their main zircon age spectra for provenance constraints.

2004; Samson et al., 2005; Gerdes and Zeh, 2006). A crucial part of the interpretations in this kind of studies relies on the comparison between the zircon age signature of the sedimentary rocks and the age signatures of the involved cratonic areas. However, the database of radiometric ages of the main sources of zircons is often not as large as would be desirable for permitting a statistically meaningful comparison. For example, the West African Craton (WAC) covers a huge extension, and the available age data of magmatic and tectono-metamorphic events is probably still insufficient to distinguish between the different parts of the craton. In contrast, the detrital zircon studies are much more abundant in the peri-Gondwanan terranes than in the sedimentary rock units of Africa deposited upon the WAC basement. For that reason, one of the aims of the present study is to date the detrital zircons of the main Neoproterozoic Groups of the Anti-Atlas belt, which were deposited overlying one of the Pan-African sutures of the northern part of the WAC. The zircon signatures of the six samples analyzed will be used to place time constraints on the Neoproterozoic stratigraphic succession, to test their provenance from the northern part of the WAC and to obtain a more robust database, especially for the Paleoproterozoic zircons, that might be used for comparison with peri-Gondwanan terranes of Europe and North America. Possible sources of zircons and their ages are shown in Fig. 1. Regarding the tectono-magmatic evolution of the Anti-Atlas belt, the ages obtained for Neoproterozoic zircons have been used to correlate the deposition of the sediments within the development of the long-lived peri-Gondwanan arc activity. Finally, one sample of a diamictite bed in the Saghro Group allowed us to correlate it with a widespread Neoproterozoic glacial period.

\section{Geological setting}

The West African Craton (WAC) is composed of three Archean and Paleoproterozoic metamorphic and magmatic shields separated by two cratonic sedimentary basins: the Reguibat Shield and the Anti-Atlas belt to the north and the Man shield to the south (Fig. 2; Ennih and Liégeois, 2008). The basement of the WAC was built through several major orogenic cycles: the Paleoarchean-Leonian cycle (different episodes between 3.5 and $3.0 \mathrm{Ga}$ ) related to continental accretion and volcano-sedimentary activity whose chronology remains uncertain(e.g. Rocci et al., 1991; Potrel et al., 1996; Kröner et al., 2001; Thiêblemont et al., 2004), the Liberian cycle(2.95-2.75 Ga; Hurley et al., 1971; Auvray et al., 1992; Potrel et al., 1998; Key et al., 2008), the Eburnian-Birimian cycle (2.2-1.75 Ga; Abouchami et al., 1990; Liégeois et al., 1991 ; Boher et al., 1992; Hirdes et al., 1992; Aït Malek et al., 1998; Schofield et al., 2006) and the Pan-African orogenic event (760-660 Ma; Leblanc and Lancelot, 1980; Saquaque et al., 1989; Hefferan et al., 2000; Thomas et al., 2002; Samson et al., 2004). One of the main char- 


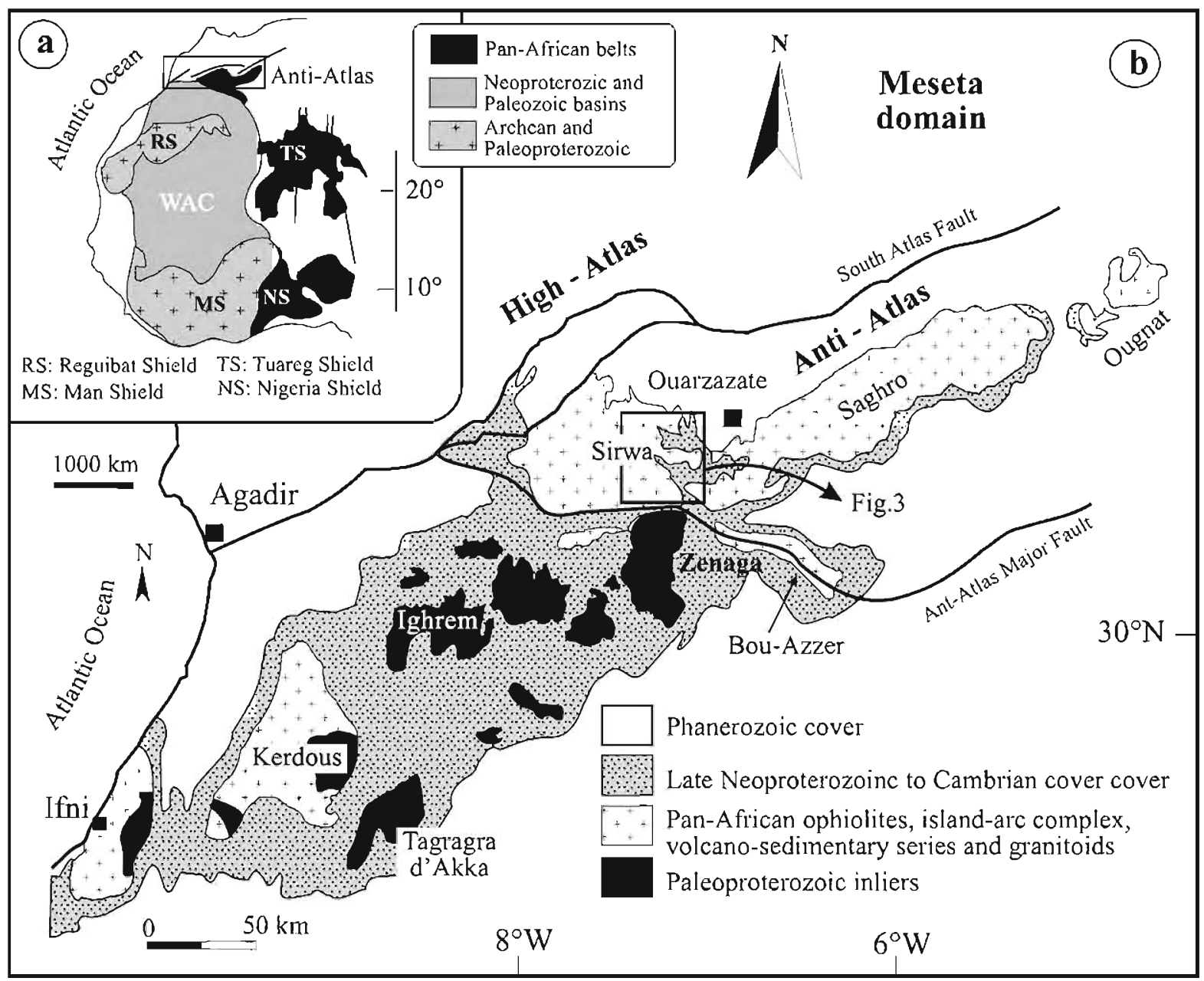

Fig. 2. (a) The Anti-Atlas belt at the northern edge of the West African Craton. (b) Geological sketch map of the Anti-Atlas belt in southern Morocco.

acteristics of the WAC is that no Mesoproterozoic events or rocks are known, suggesting a quiescent period between 1.7 and $1.0 \mathrm{Ga}$ (e.g. Ennih and Liégeois, 2008). Therefore, the lack of zircons of that age can be considered to be a typical feature of sediments sourced from the WAC. The exposed parts of the craton outcrop in two main uplifts: the Reguibat Shield in the north (Mauritania, Morocco and Algeria) and the Leo Shield in the south (Fig. 2a).

The Anti-Atlas belt of southern Morocco is located on the northern edge of WAC (Fig. 2). It is separated in the north from the High-Atlas and the Meseta domain by the South Atlas Fault (Fig. 2b) and is subdivided into three geographic domains: the western Anti-Atlas composed by Kerdous, Bas Dra, Ifni and Ighrem inliers; the central Anti-Atlas including the Sirwa, Zenaga and Bou-Azzer Inliers; and the eastern Anti-Atlas made up of Saghro and Ougnat inliers (Ennih and Liégeois, 2008; Fig. 2b). The Anti-Atlas consists essentially of: (1) basement rocks of Paleoproterozoic age (ca. $2 \mathrm{Ga}$ ) (Fig. 2b); (2) Neoproterozoic sequences with lowermost units involved in the Pan-African orogeny and (3) unconformably overlying Paleozoic rocks (Tata and Taroudant Groups; Thomas et al., 2004).

\subsection{Paleoproterozoic basement}

The Paleoproterozoic basement (2030-2200 Ma) (Aït Malek et al., 1998; Thomas et al., 2002; Walsh et al., 2002) forms the northern margin of the WAC (Fig. 2a). It outcrops in several inliers (Zenaga, Ighrem, Kerdous, Ifni, Tagragra d'Akka, etc.; Fig. 2a) and mostly consisting of phyllites, schistes, gneisses and migmatites which are intruded by calc-alkaline plutonic rocks. These basement rocks record low- to medium-grade metamorphic event attributed to the Eburnian-Birimian orogeny. The latest magmatic Paleoproterozoic event identified in the Anti-Atlas has been dated at ca. $1760 \mathrm{Ma}$ (Gasquet et al., 2005).

\subsection{Neoproterozoic sequences}

These sequences are composed of units involved in the PanAfrican orogeny and the uncomfortably overlying post-collisional volcano-sedimentary rocks (Ouarzazate Group of Thomas et al., 2002; Fig. 2b). The Neoproterozoic rocks underlying the Ouarzazate Group are subdivided into lower units (Taghdout, Bou-Azzer and Iriri Groups; Fig. 3), affected by the main Pan-African orogenic events, and the upper sequences (Saghro and Bou Salda Groups) only affected by the latest stage of Pan-African orogeny. The lower Neoproterozoic units are presumed to have been deposited over a long period of time involving a sequence of geodynamic settings starting with a rifting phase and the creation of ocean basins, and subsequent subduction-arc complex formation, and finally to arccontinent collision (Thomas et al.., 2002).

\subsubsection{Pre- to syn-Pan-African evolution}

The nomenclature and descriptions used in this section are taken mainly from Thomas et al. (2002, 2004). The break-up and rifting of the northern margin of the WAC led to the formation of a passive margin sequence (Taghdout and Lkest Groups) which consists essentially of stromatolite-bearing carbonates at the bot- 

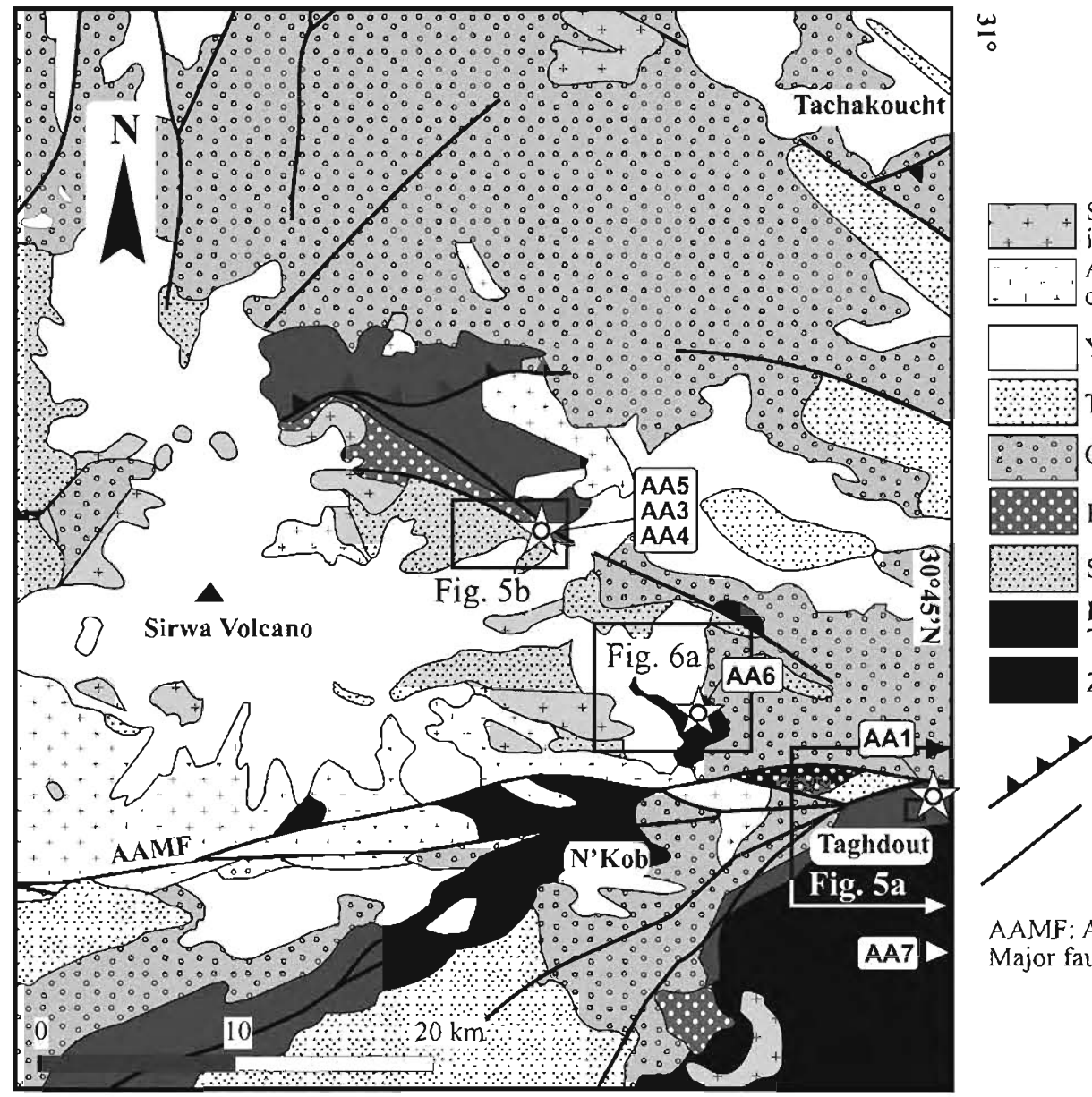

Syn-Ouarzazate Group intrusive rocks Assarag Suite (High-K calc-alkaline granitoids)

\begin{tabular}{|c|c|}
\hline & Younger cover rocks \\
\hline & Tata Group \\
\hline & Ouarzazate Group \\
\hline & Esou Salda Group \\
\hline & Saghro Group \\
\hline & $\begin{array}{l}\text { Bou Azzer, Iriri and } \\
\text { Taghdout Groups }\end{array}$ \\
\hline & Zenaga Inlier \\
\hline
\end{tabular}

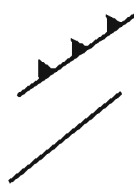

Thrust

AAMF: Anti-Atlas Major fault

Fig. 3. Simplified geological map of the Sirwa inlier (modified after Thomas et al., 2002) with the location of the samples. More detailed maps are shown in Figs. 5 and 6.

tom and quartzites at the top. In the Zenaga inlier, the Taghdout Group includes basaltic rocks underlying the limestones (Fig. 5a), and doleritic sills of continental tholeiitic signature (Ifzwane Suite) interbedded in the lower part of the sequence (Fig. 5a). The para-autochtonous passive margin sequence recorded a low-grade tectono-metamorphic event related to the Pan-African collision.

The rifting culminated with the creation of an oceanic basin between the northern edge of the WAC and an unknown terrane. The relics of the oceanic crust created (Bou-Azzer Group) are preserved in the Bou-Azzer inlier (Bou-Azzer ophiolite) and Sirwa window (Khzama Complex) as highly sheared allochthonous ophiolite complexes. Dating of plagiogranite intrusions in the Sirwa inlier indicate formation of oceanic crust at $760 \mathrm{Ma}$ (U-Pb zircon age; Samson et al., 2004), and given the absence of reliable radiometric data on the passive margin sequence, $760 \mathrm{Ma}$ is considered as the minimum age of its formation and this rifting stage may be correlated with the early Neoproterozoic break-up of the supercontinent Rodinia. After the creation of the ocean basin, a subduction phase was initiated with island-arc formation (the Iriri Group in the Sirwa inlier; Thomas et al., 2002). In the Sirwa inlier, the calc-alkaline rocks of the island-arc comprise a lowermost gneissic unit (Tachakoucht andesitic gneisses) (Huch, 1988; Bassias et al., 1988) overthrusted by an upper orthogneiss migmatitic unit (Iriri migmatite). The ophiolites and the associated arc-complex are affected by syn-collisional medium to high-grade metamorphism (Thomas et al, 2002).

The cores and overgrowths of zircon grains from the Iriri migmatite yielded two U-Pb SHRIMP ages at $743 \pm 14$ and
$663 \pm 13 \mathrm{Ma}$ respectively (Thomas et al, 2002). The older age obtained from the cores is interpreted as the age of crystallization and emplacement of the protolith to the migmatite in an islandarc complex, whereas the younger age is thought to represent the ophiolite obduction and arc accretion onto the northern edge of the WAC (Thomas et al., 2002). In the Bou Azzer inlier, U-Pb zircon dating of the gneissic and metagabbroic rocks of the Tazigzaout complex yielded similar protolith ages of $753 \pm 2$ and $743 \pm 14 \mathrm{Ma}$ respectively (D'Lemos et al., 2006). Leucogranites post-dating the gneissic and mylonitic fabrics of these rocks yielded an age of $700 \mathrm{Ma}$ (D'Lemos et al., 2006). This second magmatic phase is interpreted as a continuous arc-building event by Gasquet et al. (2008). In the Bou-Azzer inlier, the age of the main phase of Pan-African collision is constrained by syn-tectonic calc-alkaline intrusions which yielded U-Pb zircon ages of 654 and $640 \mathrm{Ma}$ (Inglis et al., 2004).

\subsubsection{Late-to post-collisional Neoproterozoic evolution}

The Pan-African collision was followed by the deposition of the Saghro Group. This group is defined in the Sirwa window by Thomas et al. (2002) as a thick pile of flysch sediments, volcanic rocks with calc-alkaline composition, volcanoclastic and clastic rocks, deformed and metamorphosed under greenschist-facies conditions (Fig. 3). These authors have defined six lithostratigraphic formations showing a lower flysch succession with the occurrence of glacial diamictites in one of the lower formations (Imghi Formation) and an upper succession with clastic deposits. Numerous geodynamic scenarios have been proposed for the Saghro Group. Most of them considered the group to be the pre-Pan-African dis- 
tal equivalent of the platform margin sequence (Taghdout Group) (Saquaque et al., 1992; Ouguir et al., 1996; Thomas et al., 2002). However, in the Saghro inlier, recent $\mathrm{U}-\mathrm{Pb}$ dating of detrital zircons from the Kellat Mgouna subgroup yielded an age of deposition of this succession between 630 and 610 Ma (Gasquet et al., 2008).

The Bou Salda Group overlies with angular unconformity the Paleoproterozoic basement and the Neoproterozoic Tagdout, BouAzzer, Iriri and Saghro Groups. The group is recognized in the Sirwa window (Thomas et al, 2002) (Fig. 3), the Kerdous and Bas Dra inliers (Anzi and Tafrawt series) and in the Bou-Azzer inlier (Tiddiline Formation). The Bou Salda Group is a volcano-sedimentary sequence which was folded during the latest Pan-African tectonic phase with local development of incipient foliation (D'Lemos et al., 2006) and a mylonitic fabric in the N'kob area (Thomas et al., 2002). The sequence show flysch and molasse features and was deposited in narrow fault-bounded troughs. In the Sirwa window, the age of the Bou Salda Group is indirectly obtained by the dating of two rhyolitic units (Tadmant and Tamriwine rhyolites) which intrude the Saghro Group and are overlain by the Ouarzazate Group, yielding $\mathrm{U}-\mathrm{Pb}$ zircon ages of $605 \pm 9$ and $606 \pm 6 \mathrm{Ma}$ (Thomas et al., 2002).

An important period of widespread magmatism characterized the late to post-Pan-African evolution. It is marked by the emplacement of a high- $\mathrm{K}$, calc-alkaline (HKCA) granitoids ( $\mathrm{Al}$ Ansari and Sagon, 1997; Errani, 2001; Ennih and Liégeois, 2001; Thomas et al., 2002) into the Saghro Group. SHRIMP U-Pb zircon dates show that this plutonic event occurred between 615 and 579 Ma (Aït Malek et al., 1998; De Wall et al., 2001; Thomas et al., 2002; Inglis et al, 2004). The Ouarzazate Group unconformably overlies the Paleoproterozoic, the Neoproterozoic sequences previously mentioned and the HKCA granitoids. It consists of a thick (up to $2000 \mathrm{~m}$ ) and extensive post-orogenic volcano-sedimentary sequence that cover most of the Anti-Atlas inliers (Fig. 3). U-Pb zircon ages of acid volcanic rocks, granites and granodiorites of the Ouarzazate Group show that this magmatic event ranged in age from 577 to $552 \mathrm{Ma}$ (Thomas et al., 2002; Walsh et al., 2002; Gasquet et al., 2005).

\section{Description of the samples and $\mathrm{U}-\mathrm{Pb}$ results}

What follows is a brief description and the laser $\mathrm{U}-\mathrm{Pb}$ results of six samples collected from the Taghdout, Saghro, Bou Salda (Sirwa inlier) and Ouarzazate Groups (Zenaga inlier), following a bottom to top order and encompassing the major units of the Neoproterozoic sequences of the Anti-Atlas. After filtering the discordant results, a variable number of analyses for each sample (between 67 and 126) have been considered valid. The schematic column of Fig. 4 shows the stratigraphic position of the samples.

\subsection{Taghdout Group}

This group consists of a volcano-sedimentary paraautochtonous unit corresponding to a passive margin shallowwater sequence, interpreted as the oldest rocks overlying the WAC (Thomas et al., 2002; 740-800? Ma).

Sample AA1 $\left(30^{\circ} 37^{\prime} 4.4^{\prime \prime} \mathrm{N} / 7^{\circ} 16^{\prime} 51.4^{\prime \prime} \mathrm{W}\right)$ : this is an undeformed pale yellow quartzite of the Mimount Formation collected from the type locality of Taghdout village (Fig. 5a), with abundant shallowwater sedimentary structures, including cross-bedding and ripples. All the zircons from this rock are very similar, with a pale pink colour and variably eroded prismatic faces. From the 131 zircon cores analyzed, we selected the fraction with $<5 \%$ of discordance in order to avoid, as far as possible, disturbances in the U-Pb system. The zircon age spectra (Figs. 6 and 7) show a major Paleoproterozoic population, a few Archean zircon grains and no Neoproterozoic zircons. The $207 / 206$ ages range from 1809 to $2936 \mathrm{Ma}$, with major peaks at 2086 and $2200 \mathrm{Ma}$ and a number of other minor peaks $(1818,1950,2005, \ldots)$ and a scarce Archean signal (only five grains) (Fig. 7). The youngest zircon found gave an age of $1809 \pm 15 \mathrm{Ma}(98 \%$ concordance) and the youngest population age is $1818 \mathrm{Ma}$, giving a maximum age of sedimentation. The oldest zircon is $2936 \pm 15$ ( $99 \%$ concordance). To facilitate the comparison between samples, we have grouped the 207/206 ages in age intervals representing the main orogenic events of the West African Craton, with the percentages of each group represented in circular diagrams (Fig. 7). The most important population, $81 \%$ of the zircons, can be related to the Eburnian-Birimian orogeny. $2 \%$ of the zircon population has ages matching the Liberian orogeny, and the remaining $17 \%$ are in the interval $2.75-2.25 \mathrm{Ga}$. The last zircon age group, present in four of the six samples, is a relevant finding of this study that will be discussed below.

\subsection{Saghro Group}

The succession of this group mainly consists of sedimentary rocks with subordinate volcanics. In the Sirwa inlier, the Saghro Group was subdivided by Thomas et al. (2002) into six formations which are from bottom to top: the Tittalt, Agchtim, Tizoula, Imghi, Azarwas and Tafiat Formations. The two upper formations correspond to coarse-grained clastic rocks, while the lowermost succession is a volcanic turbidite and flysch-like sequence (Thomas et al., 2002, 2004). The following lithological descriptions of the Imghi and Azarwas Formations, where the samples AA3, AA5 and AA6 were collected, are in part after De Kock et al. (2000) and Thomas et al. (2002, 2004).

\subsubsection{Imghi Formation (diamictite: $A A 3$ and arkose: $A A 5$ )}

This formation (Fig. $5 b$ ) is composed by thick beds of greywacke and turbidite displaying WSW-ESE paleocurrent directions (Thomas et al., 2002). It is characterized by the occurrence of several folded and faulted diamictite beds of $<1-30 \mathrm{~m}$ in thickness. The top of the sequence comprise subarkosic sandstone and quartz-pebble conglomerate with interbedded cherts. The diamictites are overlain towards the south by a succession of graded conglomerate with interbedded shale. Stratigraphic way-up structures suggest that this succession is younging to the north (Gresse et al., 2000). Bedding is well developed and dips steeply to the north. The shales are affected by an incipient cleavage which is generally parallel to bedding. The massive diamictites consist of pebbles of granite, schists, gneisses and Mimount quartzite in medium- to coarse-grained quartzo-feldspatic matrix. The clasts and the matrix are generally poorly sorted and well rounded, corresponding to second- or third-cycle deposits and show parallel slip fractures (striations). They have been interpreted as resedimented glacialderived clasts which were transported into the basin by turbidity currents (Gresse et al., 2000).

Sample $A A 5\left(30^{\circ} 44^{\prime} 49.8^{\prime \prime} \mathrm{N} / 7^{\circ} 27^{\prime} 54.3^{\prime \prime} \mathrm{W}\right)$ : it is a light-grey, fine to medium-grained immature feldspathic sandstone (arkose). It consists predominantly of quartz, plagioclase, and microcline, with minor amounts of muscovite and biotite. A mesoscopic lamination defined by lamination-parallel micas probably represents primary stratification. From 124 zircon grains analyzed, only 64 are $<5 \%$ discordant. They gave a mixture of Paleoproterozoic and Neoproterozoic dates, with a significant proportion of young zircons ( $80-20 \%$; Figs. 7 and 8 a, b). The youngest zircon found gave a date of $588 \pm 10 \mathrm{Ma}$ ( $105 \%$ concordant) and the youngest population age is $620 \mathrm{Ma}$. The oldest zircon is $2610 \pm 14$ (96\% concordant).

Sample $A A 3\left(30^{\circ} 44^{\prime} 58.0^{\prime \prime} \mathrm{N} / 7^{\circ} 27^{\prime} 50.9^{\prime \prime} \mathrm{W}\right)$ : sampled in a higher stratigraphical level of the Imghi Formation than AA5, it is an unsorted, matrix-supported and poorly stratified conglomerate level (diamictite) with a fine-grained quartzo-feldspathic matrix and numerous clastic fragments. The clasts show a gradation in 


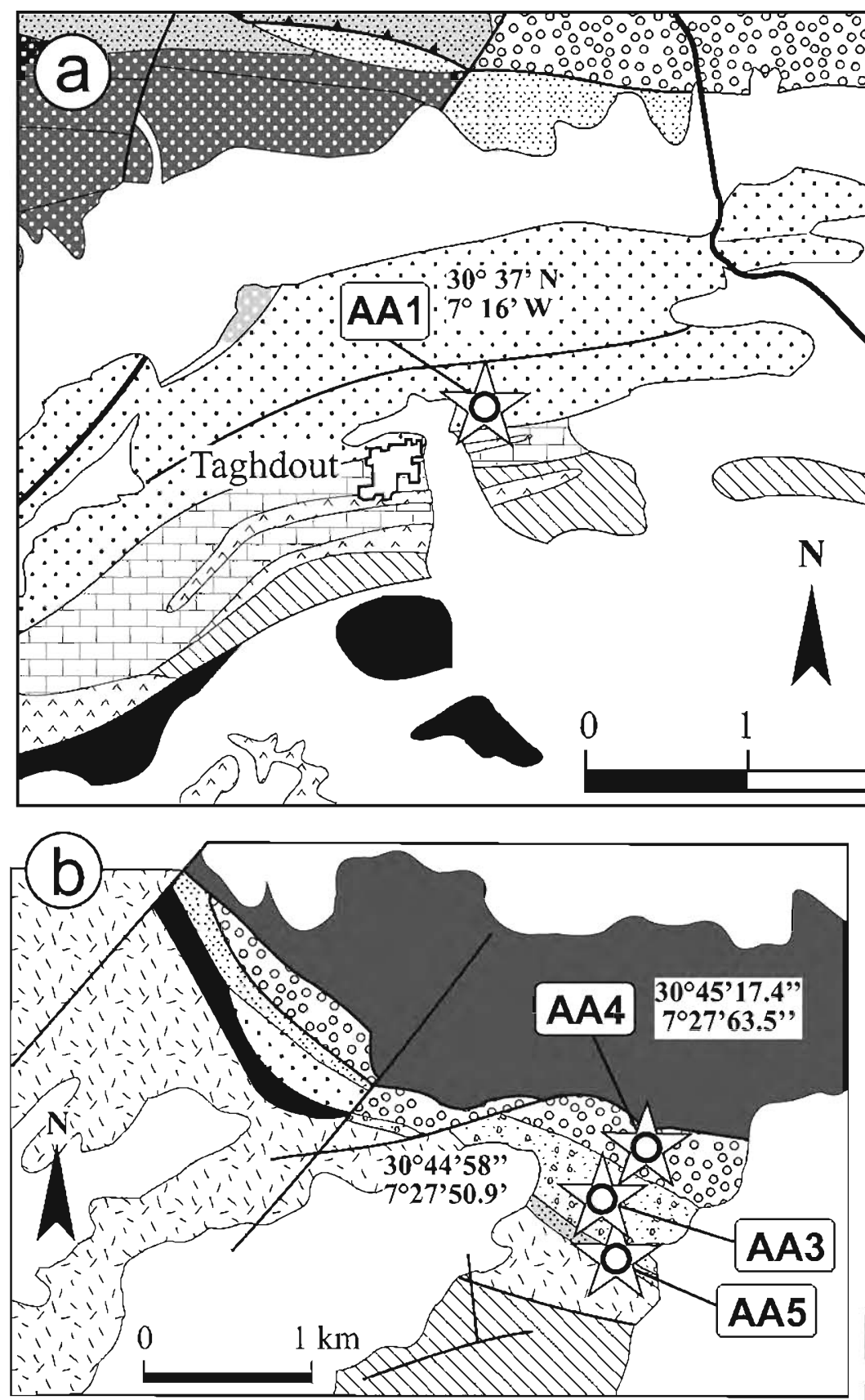

Younger cover rocks

Tata Group

:000. Ouarzazate Group

$\because \because \because$ Bou Salda Group

Saghro Group

$\because \because$ Quartzites (Mimount Fm.)

त.

Ifzwane dolerite

Dolomites

Jaspilites and cinerites

Purple Quartzites

Tamazzarra orthogneiss

(Zenaga basement)

$2 \mathrm{~km}$

Younger cover rocks

Bou Salda Group

a. Coglomerates, arkosic sandstones,

b:?: and sandstones; greywackes (a);

$6 \% 0$ quartzites (b); cherts (c).

$\therefore$, Andesites and rhyolites

Azarwas Formation

11) Arkosic sandstone, sandstone, conglomerate

Imghi Formation

Diamictites

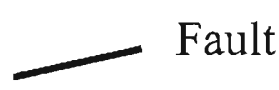

Greywackes, sandstones and shales

Tachakoucht unit: Schists, gneiss and metabasic rocks

Fig. 5. (a) Geological map of the southern part of the Sirwa inlier at Taghdout locality. (b) Geological map of the central part of the Sirwa window at the North of the Izwad Village. Modified from the 1:50.000 geological maps of the Taghdout and Tamallakout sheets (Geological Survey of Morocco, 2000).

are from bottom to top: Ighil and Lmakhzene Members (Thomas et al., 2002). The latter member essentially presents conglomerates, arkosic gritstones and sandstones with interbedded greywackes, shales, tuffs, basalts and cherts. The Ighil Member comprises basaltic rocks, andesite and rhyolite. In the N'Kob area (Fig. 3) the Bou Salda Group exhibits two other members overlying the clastic member described above: the basal member comprises rhyolitic ignimbrites, basalts and dolomites overlying the Lmekhzane sequence, and an uppermost member consisting of shales and quartzites ( Thomas et al., 2002).

Sample AA4 $\left(30^{\circ} 45^{\prime} 17.4^{\prime \prime} \mathrm{N} / 7^{\circ} 27^{\prime} 36.5^{\prime \prime} \mathrm{W}\right)$ : quartzic cobble of a conglomerate from the Lmakhzane Member collected north of Tizwad (Fig. 5b). Here, the Bou Salda Formation is bounded by subvertical strike-slip faults separating it from the Imghi and the Tachakoucht Schists at the south and the north respectively (Fig. 5b). It consists of basal andesitic rocks of the Ighil Member and the overlying conglomerate of the Lmakhzane unit. The latter is composed of massive rounded quartzic cobbles and boulders up to $1.5 \mathrm{~m}$ in diameter. Similarly to the previous sample (AA6), the proportion of Neoproterozoic/Paleoproterozoic zircons is low, with only six "young" zircons from a total concordant population of 81 (7.5\%; see circular diagram of Fig. 7). The $206 / 238$ ages are $600 \pm 12,603 \pm 13$, and $625 \pm 12 \mathrm{Ma}$ (Fig. 9a). The youngest ages provide a maximum age for the quartzite clasts in the conglomerate, and hence also for the Bou Salda Formation. The presence of Pan-African zircons precludes the possibility that the quartzite boulder came from the Taghdout quartzites. The similarity with the samples of the Saghro Group 

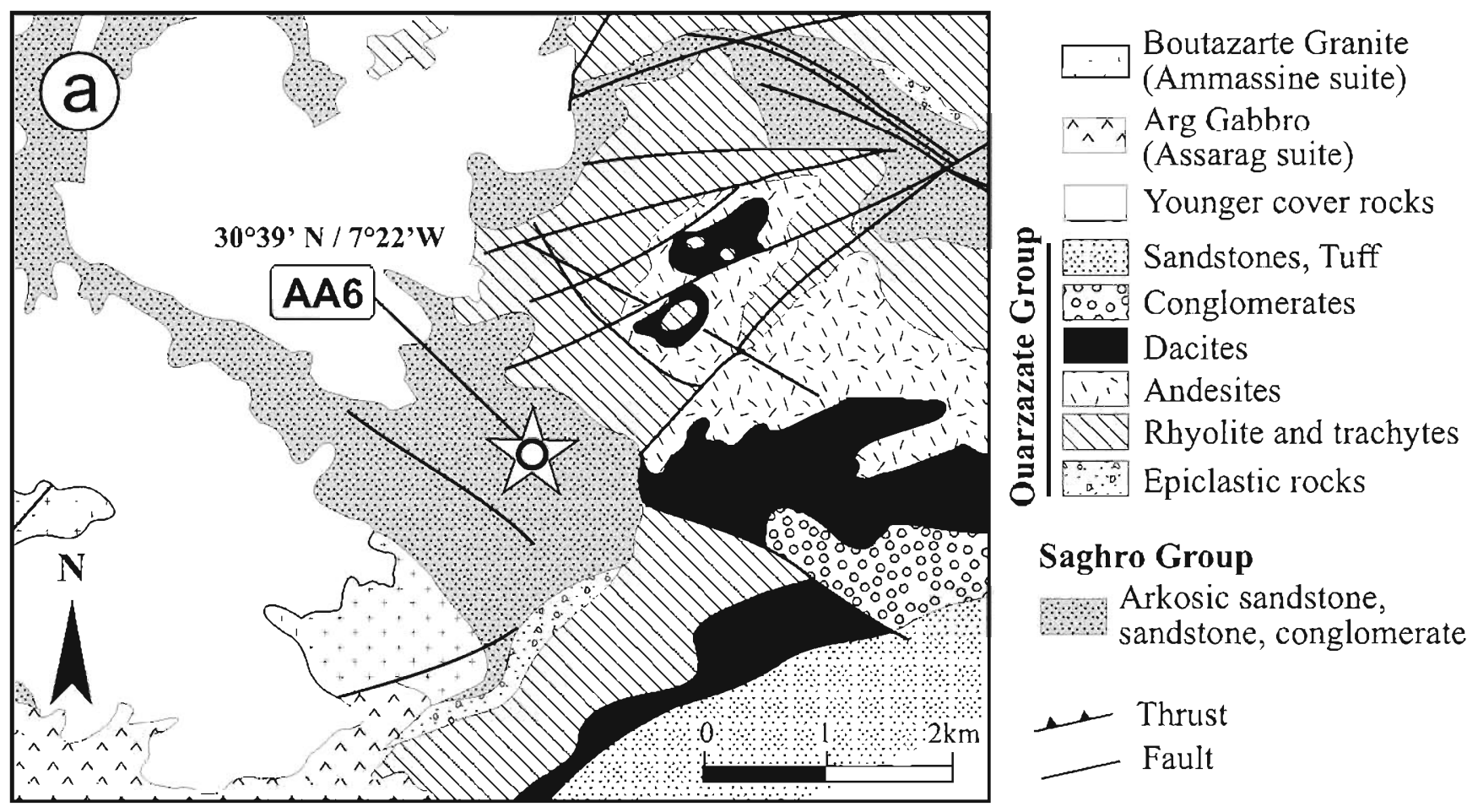

\section{Saghro Group}

Arkosic sandstone,

sandstone, conglomerate
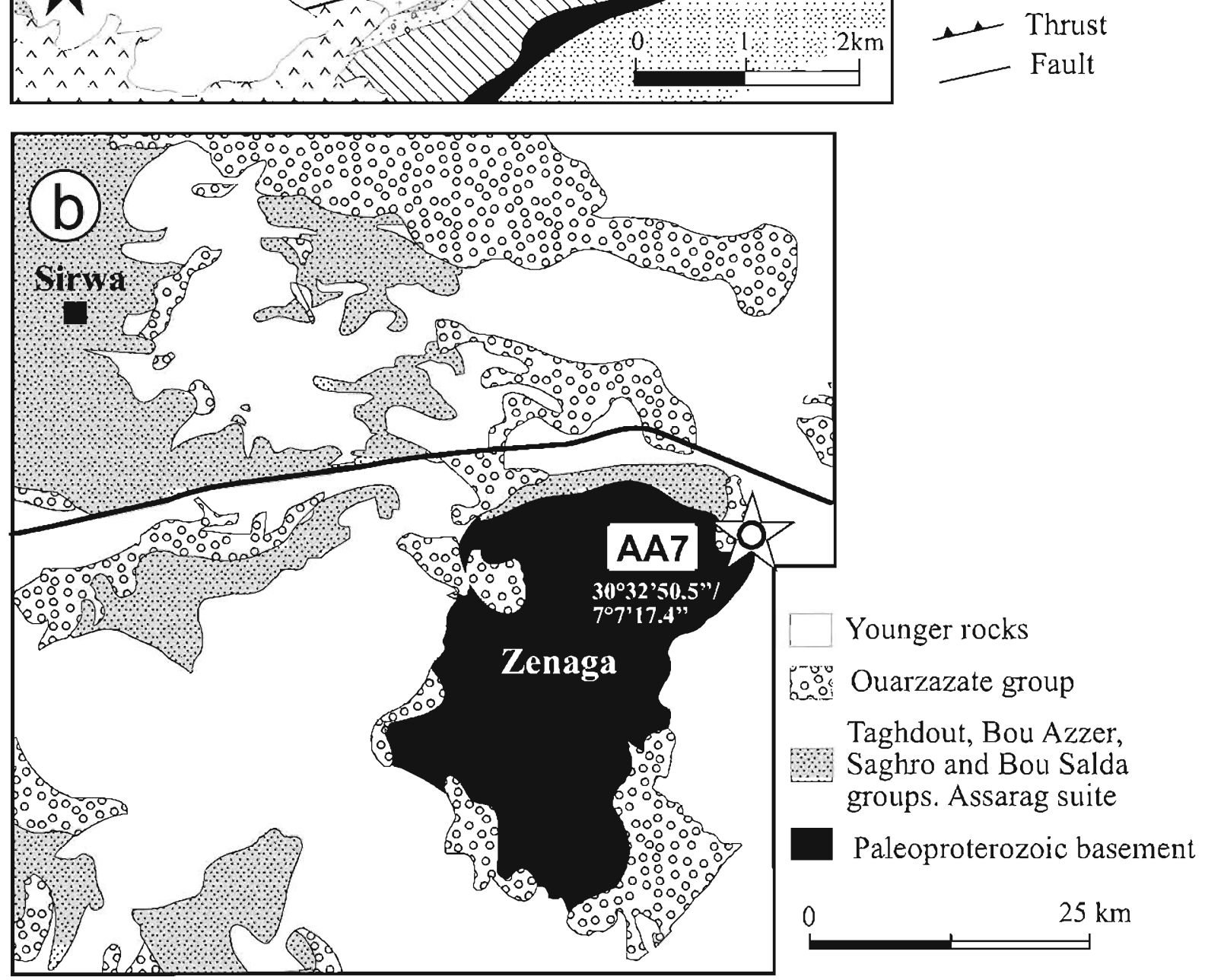

Fig. 6. (a) Geological map of southern part of the Sirwa inlier, modified from the 1:50.000 geological map of Taghdout sheet (Geological Survey of Morocco, 2000). (b) Geological sketch map of the Zenaga inlier. 


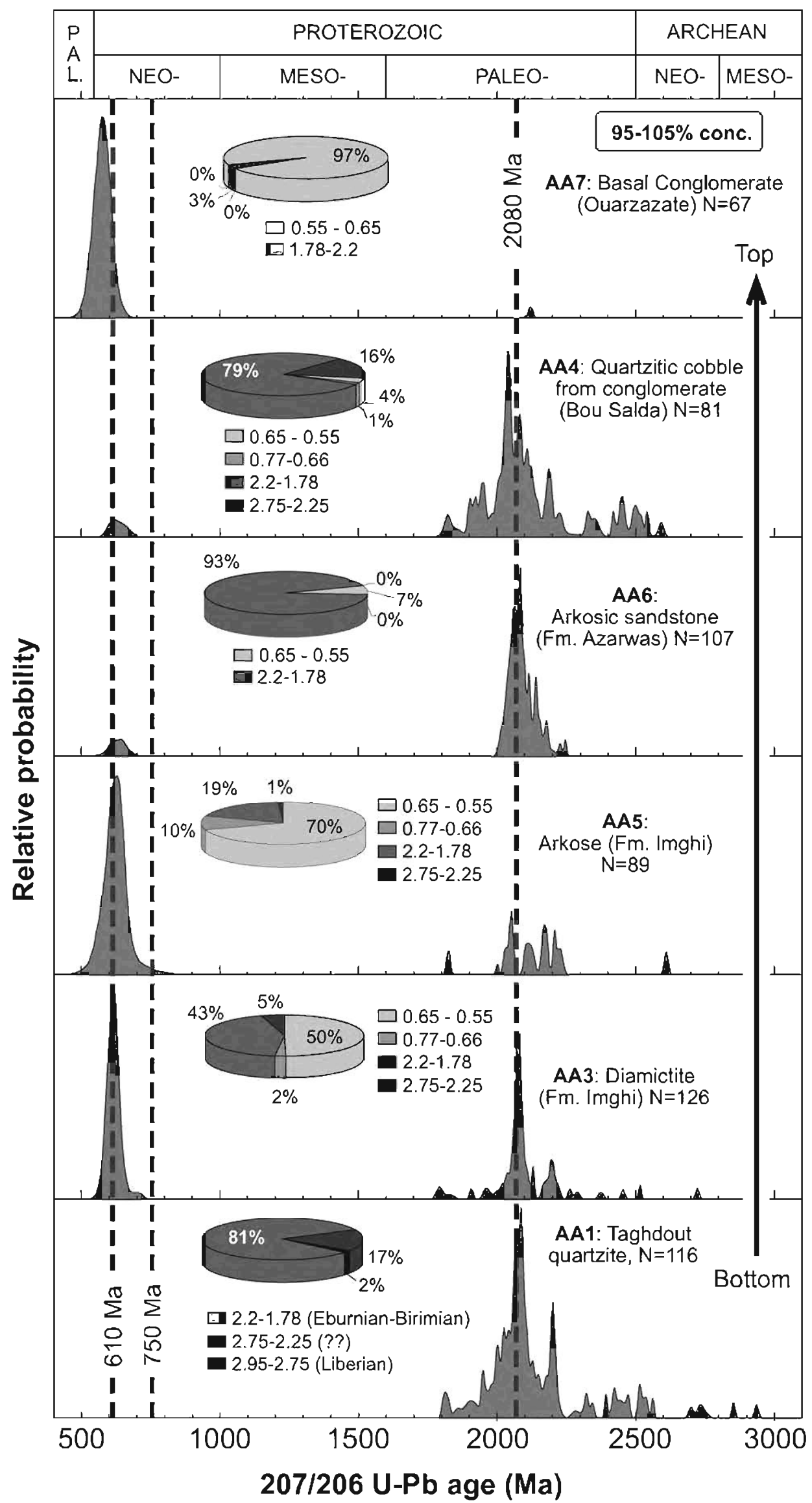

Fig. 7. Probability plots of detrital-zircon U-Pb age populations from the Neoproterozoic formations of the Anti-Atlas belt samples analyzed in this study. Plots are arranged with the oldest $s$ tratgraphic unit sampled at the bottom and the youngest unit at the top. 

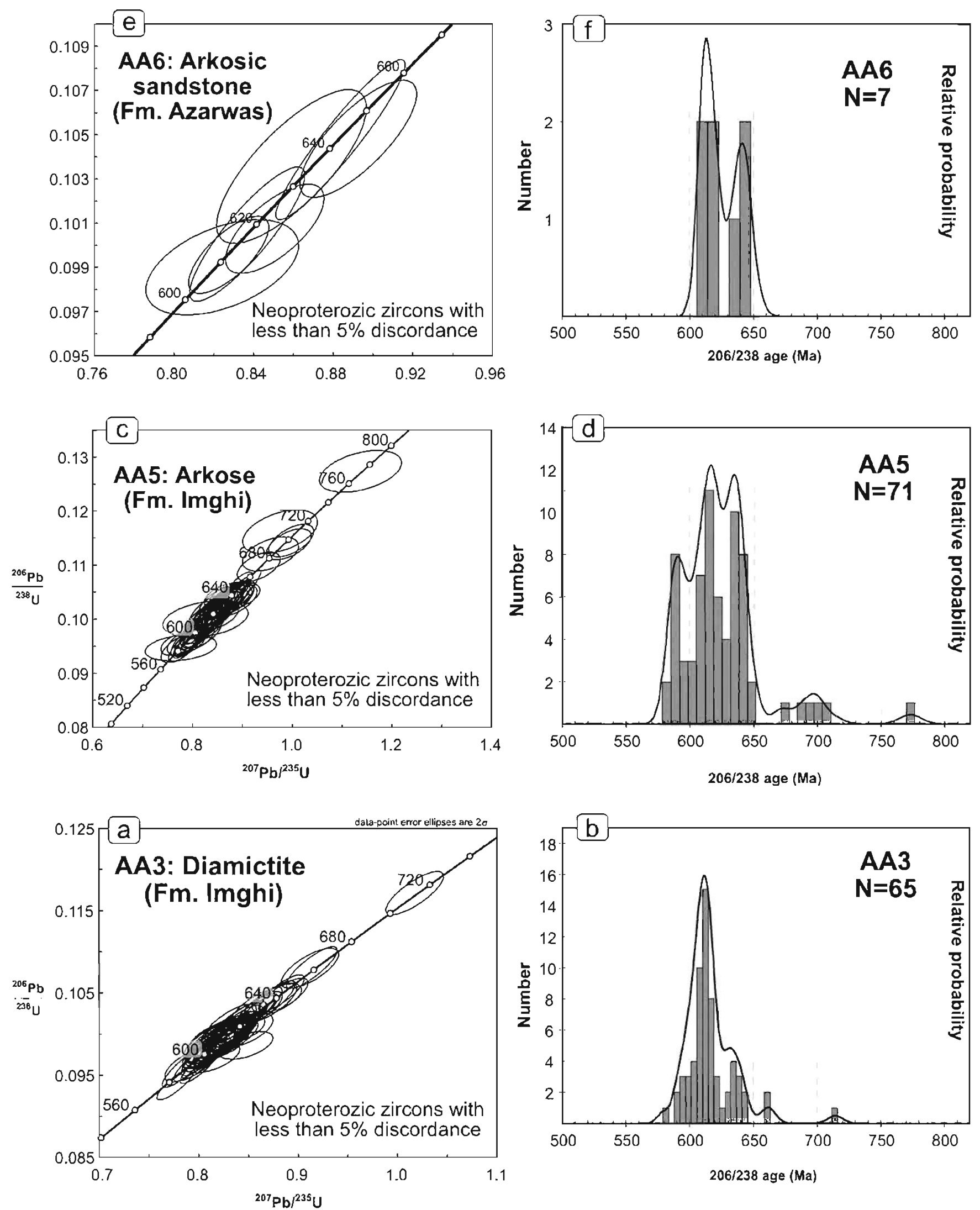

Fig. 8. U-Pb Concordia diagrams and detailed relative probability plots depicting the Neoproterozoic zircon populations for samples AA5 (a,b), AA3 (c, d) and AA6 (e, f). They are arranged from bottom to top according to their stratigraphic position. 

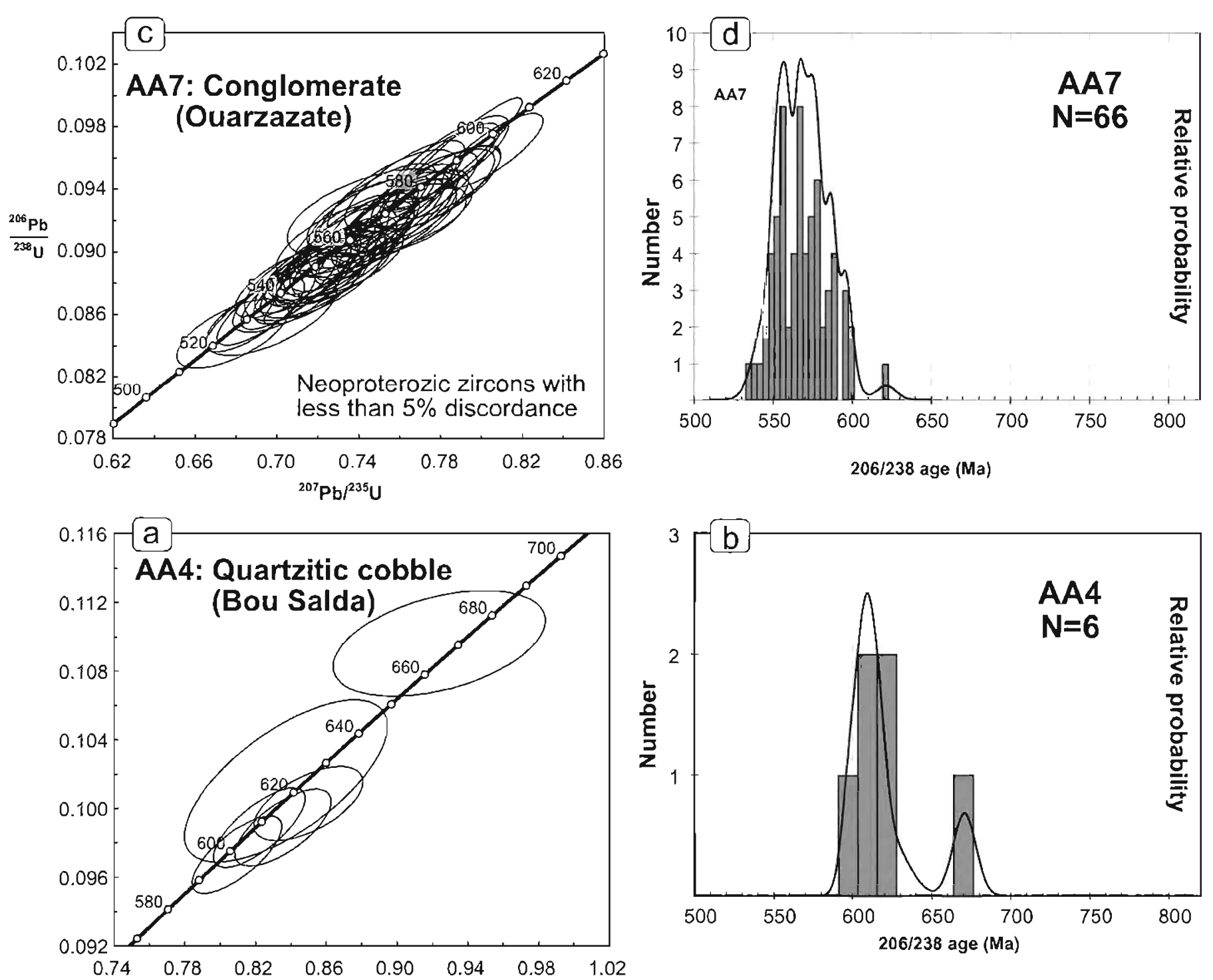

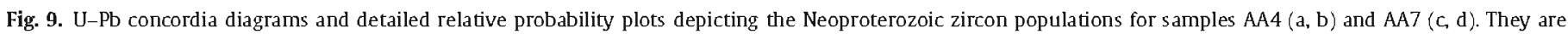
arranged from bottom to top according to their stratigraphic position.

suggests that it could be reworked sedimentary rocks from this Group.

\subsection{Ouarzazate Group}

Sample $A A 7\left(30^{\circ} 32^{\prime} 50.5^{\prime \prime} \mathrm{N} / 7^{\circ} 07^{\prime} 17.4^{\prime \prime} \mathrm{W}\right)$ : epiclastic conglomerate of the Ouarzazate Group just above the discordant contact with the materials of the Saghro Group (Fig. 6b). $97 \%$ of the zircon population is the 550-650 Ma interval, and the remaining 3\% (two grains) have 207/206 ages around $2100 \mathrm{Ma}$. The maximum of the young zircon population is $571 \mathrm{Ma}$ which, given the volcaniclastic nature of the conglomerate, is probably very close to the deposition age. The youngest zircon found was dated at $537 \pm 12 \mathrm{Ma}$ ( $96 \%$ concordance) and the youngest population age is $557 \mathrm{Ma}$. The oldest zircon gave an age of $2121 \pm 17$ ( $101 \%$ concordance).

\section{Discussion}

\subsection{Pasive margin sequence}

The age of the platform margin sequence covering the Paleoproterozoic basement (Taghdout and Lkest Groups) is not well constrained. The dikes crosscutting the basal part of the series are dated by an old $\mathrm{Rb}-\mathrm{Sr}$ whole rock at $787 \pm 10 \mathrm{Ma}$ (Cahen et al., 1984a,b). The other constrains are indirect: they are below the Bou Azzer ophiolitic complex with an obduction age of $660 \mathrm{Ma}$, and a minimum age of $788 \pm 9$ is indicated by a Rb-Sr age on clay fractions from Taghdout metasediments (Clauer, 1976). The new zircon data obtained in this study from the Taghdout quartzite (AA1) do not narrow very much the previous time constraints; the youngest zircon is $1809 \mathrm{Ma}$, thus not precluding the possibility that the sequence could be Paleoproterozoic.

The quartzite only contains Archean and Paleoproterozoic zircons, whose main characteristics are discussed below. The lack of zircons with more than $3.0 \mathrm{Ga}$ (Leonian orogeny) indicate that the provenance area of the sediments was relatively far away of the principal potential source of Meso- and Paleoarchean zircons, located in the Man and Nigerian shields in the south part of the WAC (Fig. 2; Rocci et al., 1991; Kröner et al., 2001; Thiéblemont et al., 2004). The only known source of zircons of that age in the northern part of the WAC is restricted to small parts of the Amsaga area in the Reguibat shield (Auvray et al., 1992; Potrel et al., 1996; Key et al., 2008). Therefore, the source area of the quartzites is inferred to be the proximal, authocthonous basement of the Anti-Atlas belt, 


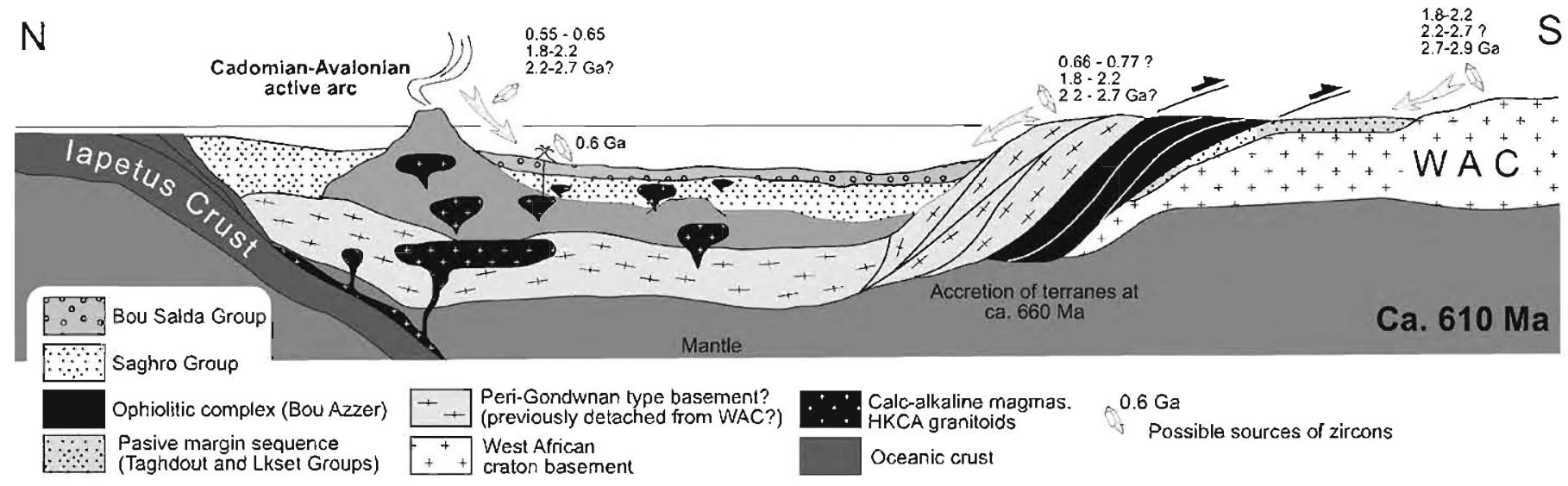

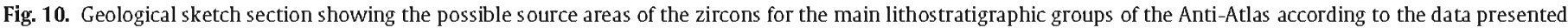
in this study.

formed essentially by Paleoproterozoic components (Fig. 10). As a more general conclusion, an interesting feature of the zircon signature of sediments whose source area is the northern part of the WAC should be the absence of more than 3.0 Ga zircons. The oldest groups of Archean zircons is very scarce and only have been found in the Taghdout quartzite (AA1), where they only represent $2 \%$ of the total zircon population. Their ages vary from 2936 to $2746 \mathrm{Ma}$, and can be ascribed to the Liberian orogeny. The following younger group of zircons, between 2.75 and $2.25 \mathrm{Ga}$, represent a significant group with a proportion $17 \%$ (see circular diagrams in Fig. 7). It is the most intriguing population, because the Archean and Paleoproterozoic evolution of the WAC does not register any tectonothermal event in that range of ages (typical zircon age ranges of the WAC are shown in Fig. 1). The youngest granitoids related with the Neoarchean development of the Reguibat shield are $2726 \pm 7 \mathrm{Ma}$ (Potrel et al., 1998; Key et al., 2008), and the following registered events are the early Eburnian ca. $2250 \mathrm{Ma}$. Thus, a gap on zircon ages between ca. 2700 and $2050 \mathrm{Ma}$ is assumed to be characteristic of rocks coming from the WAC (Nance et al., 2008). The presence of these concordant zircon ages in the platform sequence located directly over the WAC suggest that some important magmatic or orogenic event within this age interval should be registered in some part of the north WAC basement that have not been discovered yet. It is interesting to note that small populations of zircons between 2.75 and $2.25 \mathrm{Ga}$ are present in the sediments of some peri-Gondwanan terranes of NW Iberia whose source area is assumed to be the WAC (e.g. Díez Fernández et al., in press). Within the zircons of this group, the main age peaks are located at 2450 and $2514 \mathrm{Ma}$. One possible location for these basement rocks could be the Eglab Massif an the north of the Reguibat shield in Algeria, where some $\mathrm{Sr}$ and Nd model ages suggest the presence of rocks about 2.4-2.5 Ga (Peucat et al., 2005), although the ages have not been confirmed by U-Pb in zircon. The third group of zircons is the main population of zircons (83\%, Fig. 7) coming from the "old" basement $(2.2-1.78 \mathrm{Ga})$. This group is related with the important Eburnian-Birimian tectono-magmatic activity registered elsewhere in the WAC, especially in the north part of the Reguibat shield and in the basement of the Anti-Atlas belt.

\subsection{Saghro, Bou Salda and Ouarzazate Groups}

Neoarchean and Paleoproterozoic zircons. The first age group found is between 2.75 and $2.25 \mathrm{Ga}$. It is lacking in samples AA6 and AA7, represents a small proportion in samples AA3 and AA 5 ( $1 \%$ and $5 \%$ ), and only reaches a significant proportion, $17 \%$ and $16 \%$, in samples AA1 and AA4 respectively (Fig. 7). A possible source area for these zircons could be the northern terrane that should have been accreted to the WAC margin immediately after the obduction of the ohiolites (Gasquet et al., 2008; Fig. 10). This terrane would be further to the north of the Saghro arc, and at present is hidden by the south Atlas major fault (Fig. 2), but it would presumably be equivalent to the basement of the present peri-Gondwnanan Meseta terranes to the north of the Atlas chain (Ennih and Liégeois, 2008). The last group corresponds to the Eburnian cycle (2.2-1.78 Ga), and their proportion with respect to the total population varies between 93\% (sample AA6, sandstone from Azarwas Formation) and 3\% in the younger sample (AA7, Ouarzazate Group conglomerate).

Neoproterozoic zircons. The proportion of Neoproterozoic/Paleoproterozoic zircons varies considerably from the bottom to the top of the sedimentary sequence, showing the fluctuations in the source area, depending on the nature of the exhumed rocks that were being uplifted and eroded: the cratonic basement or the rocks related with the Pan-African orogeny. The oldest passive margin Taghdout quartzite (AA1), located below the suture, does not have any Neoproterozoic zircons, and going to the top of the sequences above the suture, the proportion of Neoproterozoic zircons in each sample is $80 \%$ (AA5), 52\% (AA3), 7\% (AA6), 5\% (AA4) and 97\% (AA7) (Figs. 4 and 7). The youngest zircon population in Saghro and Bou Salda Groups is 610-620 Ma, whereas in the discordantly overlying Ouarzazate Group is $557 \mathrm{Ma}$. In the case of the zircons from the Imghi Formation (arkose AA5 and diamictite AA3), the differences in the zircon population could be related with a proximal supply of sediments for the arkose and a more distal source for the diamictite, due to longer transport in ice blocks favouring a higher proportion of zircons from the Eburnian basement.

In tectono-stratigraphic reconstructions of the Anti-Atlas belt, the deformation affecting the Saghro Group was classically attributed to the Pan-African collision, and according to this view, the age of this group should be older than 660-700 Ma (Thomas et al., 2004). However, recent U-Pb zircon dating of the turbidites from the Saghro inlier place this group in the 630-610 Ma age range (Gasquet et. al., 2008). Our new data presented here from the Sirwa inlier are in the same age range. Thus, one important conclusion of this study is the confirmation that the deposition of the Saghro Group actually post-dates the accretion of the ca. $750 \mathrm{Ma}$ ophiolites and arc derived terranes (Iriri arc) to the WAC margin, which probably occurred during the second phase of the Pan-African deformation (ca. 660 Ma; D2 of D'Lemos et al., 2006). The deposition age younger than $610 \mathrm{Ma}$ demands a reassessment of the origin and stratigraphic position of the Saghro Group. The deformation described on the sediments of the Saghro Group can no longer be related with the main phase of Pan-African deformation, instead it should be ascribed to a post-610 Ma deformational 
event related with the late to post-collisional evolution. This deformation may be at the origin of the exhumation of the Pan-African metamorphic section.

Considering that the Saghro Group rest directly over the AntiAtlas suture, another interesting feature of the zircon spectra is the scarcity of 800-650 Ma zircons (at least from the Imghi Formation to the top of the sequence; Fig. 7), which implies that the source of the sediments was in some way isolated from the suture area. It is possible that a topographic barrier, e.g. accretionary prism, restricted sediment transport from the active orogen to the foreland basin (Fig. 10). The data presented in this study indicate that the source of the sediments was a terrane with north-WAC basement and a younger component of 620-580 magmatic rocks, with a major peak around $610 \mathrm{Ma}$. On the other hand, the high-K calcalkaline granites intrusive in the Saghro Group range from 615 to $580 \mathrm{Ma}$ (Aït Malek et al., 1998; De Wall et al., 2001; Levresse et al., 2001; Thomas et al., 2002; Inglis et al., 2004), being indistinguishable from the age of sedimentation of the wall rocks, with a lower limit marked by the age of the discordant overlying sequence, the Ouarzazate Group, that show intrusive igneous rocks of ca. $580 \mathrm{Ma}$ (Toufghrane Suite; Mifdal and Peucat, 1985; Thomas et al., 2002). Thus, the age of deposition and the intrusion of granitoids seems closer than the resolution limit of the radiometric dating, suggesting a highly active geodynamic realm where magmatism, relief formation, erosion and sedimentation occurs at a high velocities. This apparent synchronicity of the sedimentation and their subsequent metamorphism and intrusion by plutonic bodies is a typical feature of magmatic arc settings (Abati et al., 2003), and therefore we propose that the Saghro Group come from the erosion of a terrane located further to the north of the Anti-Atlas suture, probably a magmatic arc built upon WAC basement. The arc should have been incipiently detached from its margin, in a way that most of the detrital material came from the arc itself and their basement, and permitting only limited communication with the suture area (Fig. 10). This possible arc activity of ca. 610 Ma could be correlated with the long-lived arc surrounding the northern Gondwana margin (Fig. 1), characterized by abundant calc-alkaline volcanic rocks and cogenetic plutons, sedimentation and deformation associated with the opening and closing of arc-related basins that gave rise to the peri-Gondwanan terranes and finally to the opening of the Rheic Ocean (e.g. Murphy and Nance, 1989; Keppie et al., 1996; Murphy et al., 2004; Nance et al., 2008). The different proportions of sediments coming from the arc with respect to the basement can be interpreted in terms of the birth, development and erosive dismantling of the arc. The strong signal of $\mathrm{ca}$. $650-550 \mathrm{Ma}$ ( $50 \%$ of the zircons) appearing in sample AA3, reaching a maximum of $70 \%$ in sample AA5 (Fig. 7) would be related with the formation of the arc. The subsequent decreasing of this group of zircons going to higher stratigraphical levels (7\% and $4 \%$ in samples AA6 and AA4) would be associated with the progressive dismantling of the arc.

According to the former interpretation of the age of the Saghro Group, the diamictite beds that appear in the Imghi Formation have been correlated with the Sturtian glacial period ca. $700 \mathrm{Ma}$ (Thomas et al., 2002, 2004). However, the zircons from one sample of these diamictites (sample AA3) indicate that the correlation cannot be maintained longer, and instead they should be correlated with the Marinoan glacial period ca.630-610 Ma (Kennedyet al., 1998), with a widespread distribution of glaciogenic deposits in West Africa (Deynoux et al., 2006).

\section{Conclusions}

1. The lack of zircons older than 3.0 Ga indicates that the source of the Neoproterozoic sedimentary sequences of the Anti-Atlas belt was the northern part of the WAC autochthonous basement (Reguibat shield).
2. The group of Neoarchean-Paleoproteroic zircons (2.75-2.25) suggests the existence of a tectonothermal event(s) in the northern part of the WAC with a peak at ca. 2.5-2.4 Ga, which have not been described yet.

3. The major zircon source of the sediments was the igneous and metamorphic Eburnian rocks located in the Reguibat shield (except for the Ouarzazate Group).

4. The depositional age of the Saghro Group is younger than 620-610 Ma and hence the deformation that affects the sediments should be late- to post-collisional.

5. The sedimentary sequences of the Saghro Group probably reflects the development and subsequent erosive dismantling of a magmatic arc located to the north of the Pan-African suture and built upon north WAC basement.

6. This arc can be correlated with the long-lived arc-system surrounding the northern Gondwana margin during the Neoproterozoic-Lower Cambrian.

7. The diamictite beds appearing in the Sagrho Group are related to the Marinoan glacial period.

\section{Acknowledgments}

We would like to express our thanks to Bob Thomas, an anonymous reviewer and the editor P. Cawood for helpful and constructive reviews. Field work was funded by project A-7287-06 from the Agencia Española de Cooperaciôn Internacional (AECI), and analytical work was funded by project CM-UCM-910129 from the Comunidad de Madrid.

\section{Appendix A. Supplementary data}

Supplementary Frei and Gerdes, 2009; Gerdes and Zeh, 2009; Jackson et al., 2004; Janousek et al., 2006; data associated with this article can be found, in the online version, at doi:10.1016/j.precamres.2010.05.018.

\section{References}

Abati, J., Arenas, R., Martínez Catalán, J.R., Díaz García, F., 2003. Anticlockwise P-T path of granulites from the Monte Castelo Gabbro (Ordenes Complex, NW S.pain). Journal of Petrology 44(2), 305-327.

Abouchami, W., Boher, M., Michard, A., Albarede, F., 1990. A major 2.1 Ga event of Mafic magmatism in West Africa: an early stage of crustal accretion. Journal of Geophysical Res earch 95, 17605-17629.

Aït Malek, H., Gasquet, D., Bertrand, J.M., Leterrier, J., 1998. Eburnian and Panafrican granitoids from the Igherm, Kerdous and Bas-Draa Proterozoic inliers (western Anti-Atlas, Morocco): U-Pb geochronology on zircon. Comptes Rendus de l'Academie des Sciences Series IIA Earth and Planetary Science 327, 819-826.

Al Ansari, A., Sagon, J.P., 1997. Le gisement d'or de Tiouit (Jbel Saghro, Anti-Atlas, Maroc) Un système mêsothermal polyphasé à sulfures-or et hématite-or dans une granodiorite potassique d’âge protérozoïque supérieur. Chronique de la Recherche Minière 527, 3-25.

Auvray, B., Peucat, J.-J., Potrel, A., Burg, J.-P., Caruba, C., Dars, R., Lo, K., 1992. Données géochronologiques nouvelles sur l'Archéen de l'Ams aga (Dorsale Réguibat Mauritanie). Comptes rendus de l'Académie des sciences 315 (1), 63-70.

Avigad, D., Kolodner, K., McWilliams, M., Persing, H., Weissbrod, T., 2003. Origin of northem Gondwana Cambrian sandstone revealed by detrital zircon SHRIMP dating. Geology 31 (3), 227-230.

Bassias, Y., Wallbrecher, E., Willgallis, A., 1988. Tectonothermal evolution of the late Panafrican Orogeny in the central Anti-Atlas (Southern Morocco). The Atlas System of Morocco, 43-60.

Boher, M., Abouchami, W., Michard, A., Albarede, F., Arndt, N.T., 1992. Crustal growth in West Africa at 2.1 Ga. Journal of Geophysical Research 97, 345-369.

Cahen, L., Snelling, N.J., Delhah J., Vail, J.R., Bonhomme, M., Ledent, D., 1984a. The Geochronology and Evolution of Africa. Ox ford University Press, 512 pp.

Cahen, L., Snelling, N.J., Delhal, J., Vail, J.R., Bonhomme, M., Ledent, D., 1984b. The Beochronology and Evolution of Africa. Oxford University Press, 512 pp.

Clauer, N., 1976. Géochimie isotopique du strontium des milieux sédimentaires. Application à la géochronologie de la couverture du craton ouest-africain. Sciences Géologiques Mémoires, Strasbourg 45, 256

De Kock, G.S., De Beer, C.H., Chevallier, L.P., Gresse, P.G., Thomas, R.J., 2000. Mémoire Explicative de la Carte Géologique du Maroc au 1/50,000, feuille Taghdout. Notes et Mémoires Service Géologique du Maroc 396, 142. 
De Wall, H., Kober, B., Greiling, R.O., Errami, E., Ennih, N., Abstract 2001. Age and structural setting of the grantoid emplacement in the area of Imiter (Eastern Saghro). In: 2nd Coll. 3M. Marrakech, p. 19.

Deynoux, M., Affaton, P., Trompette, R., Villeneuve, M., 2006. Pan-African tectonic evolution and glacial events regis tered in Neoproterozoic to Cambrian cratonic and foreland basins of West Africa. Joumal of African Earth Sciences 46 (5), $397-426$.

Díez Fernández, R., Martínez Catalán, J.R., Gerdes, A., Abati, J., Arenas, R., FemándezSuárez, J., in press. U-Pb ages of detrital zircons from the Basal allochthonous units of NW Iberia: provenance and paleoposition on the northern margin of Gondwana during the Neoproterozoic and Paleozoic. Gondwana Research. doi:10.1016/j.gr.2009.12.006.

D'Lemos, R.S., Inglis, J.D., Samson, S.D., 2006. A newly discovered orogenic event in Morocco: Neoproterozic ages for supposed Eburnean basement of the Bou Azzer inlier, Anti-Atlas Mountains. Precambrian Res earch 147 (1-2), 65-78.

Ennih, N., Liégeois, J.-P., 2008. The boundaries of the West African Craton, with special reference to the basement of the Moroccan metacratonic Anti-Atlas belt Geological Society, London, Special Publications 297 (1), 1-17

Ennih, N., Liégeois, J.-P., 2001. The Moroccan Anti-Atlas: the West African Craton passive margin with limited Pan-African activity. Implications for the northern limit of the craton. Precambrian Research 112(3-4), 289-302.

Errami, E., 2001. Les granitoïdes panafricains post-collisionnels du Saghro oriental (Anti-Atlas, Maroc). Etude pétrologique et structurologique par l'Anisotropie de Susceptibilité Magnétique (ASM). Université El Jadida, El Jadida, 265 pp.

Fernández-Suárez, J., Díaz García, F., Jeffries, T.E., Arenas, R., Abati, J., 2003. Constraints on the provenance of the uppermost allochthonous terrane of the NW Iberian Massif: inferences from detrital zircon U-Pb ages. Terra Nova 15 (3), $138-144$.

Femández-Suárez, J., Gutiérrez Alonso, G., Jeffries, T.E., 2002. The importance of along-margin terrane transport in northern Gondwana: insights from detrital zircon parentage in Neoproterozoic rocks from Iberia and Brittany. Earth and Planetary Science Letters 204(1-2), 75-88.

Frei, D., Gerdes, A., 2009. Precise and accurate in situ U-Pb dating of zircon with high sample throughput by automated LA-SF-ICP-MS. Chemical Geology 261 (3-4), 261-270.

Gasquet, D., Levresse, G., Cheilletz, A., Azizi-Samir, M.R., Mouttaqi, A., 2005. Contribution to a geodynamic reconstruction of the Anti-Atlas (Morocco) during Pan-African times with the emphasis on inversion tectonics and metallogenic activity at the Precambrian-Cambrian transition. Precambrian Research 140 (3-4), 157-182

Gasquet, D., Ennih, N., Liégeois, J.P., Soulaimani,A., Michard,A., 2008. The Pan-African belt continental evolution. The Geology of Morocco, 33-64.

Geological Survey of Morocco (2000). Geological Map of Morocco 1/50,000; sheets no 394 (Tamallakout) and no 396 (Taghdout)

Gerdes, A., Zeh, A., 2006. Combined U-Pb and Hf isotope LA-(MC-)ICP-MS analyses of detrital zircons: comparison with SHRIMP and new cons traints for the provenance and age of an Armorican metasediment in Central Germany. Earth and Planetary Science Letters $249(1-2), 47-61$.

Gerdes, A., Zeh, A., 2009. Zircon formation versus zircon alteration - new insights from combined U-Pb and Lu-Hf in-situ LA-ICP-MS analyses, and consequences for the interpretation of Archean zircon from the Central Zone of the Limpopo Belt. Chemical Geology 261 (3-4), 230-243.

Gresse, P.G., de Beer, C.H., Chevalier, L.P., de Kock, G.S., Thomas, R.J., 2000. Mémoire explicatif de la carte géologique du Maroc au 1/50,000, feuille Tachoukacht. Notes et Mémoires Service Géologique du Maroc, 393b.

Hefferan, K., Admou, H., Karson, J.A., Saquaque, A., 2000. Anti-Atlas (Morocco) role in Neoproterozoic Western Gondwana reconstruction. Precambrian Research $103,89-96$.

Hirdes, W., Davis, D.W., Eisenlohr, B.N., 1992. Reassess ment of Proterozoic granitoid ages in Ghana on the basis of $\mathrm{U} / \mathrm{Pb}$ zircon and monazite dating. Precambrian Research $56(1-2), 89-96$

Huch, K.M., 1988. Die Panafrikanische Khzama-geosutur im zentralen Anti-Atlas, Marokko. Freie University, Berlin, 172 pp.

Hurley, P.M., Leo, G.W., White, R.W., Fairbairn, H.W., 1971. Liberian age province (about 2700 m.y.) and adjacent provinces in Liberia and Sierra Leone. Geological Society of America Bulletin 82 (12), 3483-3490.

Inglis, J.D., MacLean, J.S., Samson, S.D., D’Lemos, R.S., Admou, H., Hefferan, K., 2004 A precise U-Pb zircon age for the Bleïda granodiorite, Anti-Atlas, Morocco: implications for the timing of deformation and terrane assembly in the eastern Anti-Atlas. Journal of African Earth Sciences 39 (3-5), 277-283.

Jackson, S.E.,Pearson, N.J., Griffin, W.L., Belousova, E.A., 2004. The application of laser ablation-inductively coupled plasma-mass spectrometry to in situ U-Pb zircon geochronology. Chemical Geology 211, 47-69.

Janousek, V., Gerdes, A., Vrana, S., Finger, F., Erban, V., Friedl, G., Braithwaite, C.J.R., 2006. Low-pressure granulites of the Lisov Massif, Southem Bohemia: visean metamorphism of late Devonian Plutonic Arc Rocks. Journal of Petrology 47 (4), $705-744$.

Kennedy, M.J., Runnegar, B., Prave, A.R., Hoffmann, K.-H., Arthur, M.A., 1998. Two or four Neoproterozoic glaciations? Geology 26 (12), 1059-1063

Keppie, J.D., Dostal, J., Murphy, J.B., Nance, R.D., 1996. Terrane transfer between eastern Laurentia and western Gondwana in the early Paleozoic: constraints on global reconstructions. Geological Society of America, Special Papers 304, $369-380$.

Key, R.M., Loughlin, S.C., Gillespie, M., Del Rio, M., Horstwood, M.S.A., Crowley, Q.G., Darbyshire, D.P.F., Pitfield, P.E.J., Henney, P.J., 2008. Two Mesoarchaean terTanes in the Reguibat shield of NW Mauritania. Geological Society, London, Special Publications 297 (1), 33-52.

Kröner, A., Ekwueme, B.N., Pidgeon, R.T., 2001. The oldest rocks in West Africa: SHRIMP zircon age for early archean migmatitic orthogneiss at Kaduna, Northern Nigeria. The Journal of Geology 109 (3), 399-406.

Leblanc, M., Lancelot, J.R., 1980. Interprétation géodynamique du domaine panafricain (Précambrien terminal) de l'Anti-Atlas (Maroc) à partir de données géologiques et géochronologiques. Canadian Journal of Earth Sciences 17 (1) $142-155$.

Levresse, G., Azizi, M.S., Cheilletz,A., Gasquet, D., Zyadi, R., Ennaciri, D., Archibald, D. Ouguir, H., Abstract 2001. Le gis ement Ag-Hg d'Imiter (Anti-Atlas, Maroc): Nouvelles donneés $\mathrm{U}-\mathrm{Pb},{ }^{40} \mathrm{Ar} /{ }^{39} \mathrm{Ar},{ }^{* 34} \mathrm{~S}$ et micros tructurales appuyant le modéle génétique hydrothermal-épithermal. In: 2nd Coll. 3M. Marrakech, p. 97.

Liégeois, J.P., Claessens, W., Camara, D., Klerkx, J., 1991. Short-lived Eburnian orogeny in southern Mali. Geology, tectonics, U-Pb and Rb-Sr geochronology. Precambrian Research 50 (1-2), 111-136.

Linnemann, U., McNaughton, N.J., Romer, R.L., Gehmlich, M., Drost, K., Tonk, C. 2004. West African provenance for Saxo-Thuringia (Bohemian Massif): Did Armorica ever leave pre-Pangean Gondwana? - U/Pb-SHRIMP zircon evidence and the Nd-is otopic record. International Journal of Earth Sciences 93 (5), 683-705.

Linnemann, U., Gerdes, A., Drost, K., Buschmann, B., 2007. The continuum between Cadomian orogenesis and opening of the Rheic Ocean: constraints from LA-ICPMS U-Pb ziecon dating and analysis of plate-tectonic setting (Saxo-Thuringian zone, northeas tern Bohemian Massif, Germany). Geological Society of America, Special Papers 423, 61-96

Mifdal, A., Peucat, J.J., 1985. Datations U-Pb et Rb-Sr du volcanisme acide de l'AntiAtlas marocain et du socle sous-jacent dans la region de Ouarzazate. Apport au probleme de la limite Precambrien-Cambrien. Sciences Geologiques Bulletin, Strasbourg 38 (2), 185-200.

Murphy, J.B., Nance, R.D., 1989. Model for the evolution of the Avalonian-Cadomian belt Geology 17(8), 735-738.

Murphy, J.B., Pisarevsky, S.A., Nance, R.D., Keppie, J.D., 2004. Neoproterozoic-early Paleozoic evolution of peri-Gondwanan terranes: implications for LaurentiaGondwana connections. International Journal of Earth Sciences 93 (5), 659-682.

Nance, R.D., Murphy, J.B., Strachan, R.A., Keppie, J.D., Gutiertez-Alonso, G. Femández-Suárez, J., Quesada, C., Linnemann, U., D’lemos, R., Pisarevsky, S.A., 2008. Neoproterozoic-early Palaeozoic tectonostratigraphy and palaeogeography of the peri-Gondwanan terranes: Amazonian v. West African connections Geological Society, London, Special Publications 297 (1), 345-383.

Ouguir, H., Macaudiere, J., Dagallier, G., 1996. Le protérozoïque supérieur d'imiter, Saghro oriental, Maroc: un contexte géodynamique d'arrièré-arc. Joumal of African Earth Sciences 22 (2), 173-189.

Peucat, J.-J., Capdevila, R., Drareni, A., Mahdjoub, Y., Kahoui, M., 2005. The Eglab massif in the West African Craton (Algeria), an original segment of the Eburnean orogenic belt: petrology, geochemistry and geochronology. Precambrian Research 136 (3-4), 309-352.

Potrel, A., Peucat, J.J., Fanning, C.M., Auvray, B., Burg, J.P., Caruba, C., 1996. 3.5 Ga old terranes in the West African Craton, Mauritania. Journal of the Geological Society 153 (4), 507-510.

Potrel, A., Peucat, J.J., Fanning, C.M., 1998. Archean crustal evolution of the West African Craton: example of the Amsaga Area (Reguibat Rise). U-Pb and Sm-Nd evidence for crustal growth and recycling. Precambrian Research 90, 107-117.

Rocci, G., Bronner, G., Deschamps, M. (Eds.), 1991. Crystalline basement of the West African Craton. The West African Orogens and Circum-Atlantic Correlatives, Springer-Verlag, Berlin, 31-61 pp.

Samson, S.D., D’Lemos, R.S., Miller, B.V., Hamilton, M.A., 2005. Neoproterozoic palaeogeography of the Cadomia and Avalon terranes: constraints from detrital zircon U-Pb ages. Journal of the Geological Society $162(1), 65-71$

Samson, S.D. Inglis, J.D., D'Lemos, R.S., Admou, H., Blichert-Toft, J., Hefferan, K., 2004 Geochronological, geochemical, and Nd-Hf isotopic constraints on the origin of Neoproterozoic plagiogranites in the Tasriwine ophiolite, Anti-Atlas orogen, могосco. Precambrian Research 135 (1-2), 133-147.

Saquaque, A., Admou, H., Karson, J., Hefferan, K., Reuber, I., 1989. Precambrian accretionary tectonics in the Bou Azzer-El Graara region, Anti-Atlas, Morocco. Geology 17 (12), 1107-1110.

Saquaque, A., Benharref, M., Abia, H., Mrini, Z., Reuber, I., Karson, J., 1992. Evidence for a Panafrican volcanic arc and wrench fault tectonics in the Jbel Saghro, AntiAtlas, Morocco. Geologische Rundschau 81 (1), 1-13.

Schofield, D.I., Hors twood, M.S.A., Pitfield, P.E.J., Crowley, Q.G., Wilkinson, A.F. Sidaty, H.C.O., 2006. Timing and kinematics of Eburnean tectonics in the centra Reguibat Shield, Mauritania. Journal of the Geological Society 163 (3), 549-560.

Stacey, J.S., Kramers, J.D., 1975. Approximation of terrestrial lead isotope evolution by a two-stage model. Earth and Planetary Science Letters 26 (2), 207-221.

Thiéblemont, D., Goujou, J.C., Egal, E., Cocherie, A., Delor, C., Lafon, J.M., Fanning, C.M. 2004. Archean evolution of the Leo Rise and its Eburnean reworking. Journal of African Earth Sciences 39 (3-5), 97-104.

Thomas, R.J., Chevallier, L.P., Gresse, P.G., Harmer, R.E., Eglington, B.M., Armstrong R.A., de Beer, C.H., Martini, J.E.J., de Kock, G.S., Macey, P.H., Ingram, B.A., 2002. Precambrian evolution of the Sirwa Window, Anti-Atlas Orogen, Morocco. Precambrian Research 118 (1-2), 1-57.

Thomas, R.J., Fekkak, A., Ennih, N., Errami, E, Loughlin, S.C. Gresse, P.G., Chevallier, L.P., Liégeois, J.P., 2004. A new lithostratigraphic framework for the Anti-Atlas Orogen, Morocco. Journal of African Earth Sciences 39 (3-5), 217-226.

Walsh, G.J., Aleinikoff, J.N., Benziane, F., Yazidi, A., Armstrong, T.R., 2002. U-Pb zircon geochronology of the Paleoproterozoic Tagragra de Tata inlier and its Neoproterozoic cover, western Anti-Atlas, Morocco. Precambrian Research 117, 1-20. 